Transport, Mr. S. Swingler, said that planned capital investment in the ports in $1965-66$ was $£ 29.9$ million. compared with $£ 18$ million in 1964-65, and under the National Plan would rise to $£ 51$ million in $1966-67$ and to $£ 63$ million in 1967-68. Work on the Tilbury development scheme of the Port of London Authority had been put in hand to the extent of $£ 10$ million. Improvements to the Royal Edward Dock at Avonmouth had been authorized to the extent of $£ 750,000$. Work was about to start on the new lock at Grangemouth under a $£ 7$ million scheme. Work was also in hand at Leith which represented an investment of $£ 6$ million. The Portbury scheme put forward by the Port of Bristol Authority was an imaginative scheme of great merit and was being very earefully considered, but $\mathrm{Mr}$. Swingler was not able to announce a decision.

\section{Finance for Research and Development}

In written answers in the House of Commons on March 9, the Minister of State, Department of Education and Science, Mr. R. E. Prentice, stated in 1964-65 research and development in the United Kingdom financed from Government sources was provisionally estimated at $£ 427$ million. Of this, $£ 177$ million was in Government research establishments, $£ 49$ million in universities and technical colleges; and $£ 187$ million in industry; for $1955-56$, the corresponding figures were $£ 222 \cdot 2$ million; $£ 78.3$ million; $£ 11.8$ million; and $£ 128.4$ million, respectively; in $1958-59$, £316.1 million; £134.9 million; $£ 18.7$ million; and $£ 155.9$ million; and in 1961-62, $£ 385$ million; $£ 163.1$ million; $£ 27.6$ million; and $£ 180.5$ million, respectively. It was estimated that in 1964 about 7,000 scientists and engineers emigrated from Britain and there were about 4,500 immigrants.

\section{British Research and Development Reports}

THE first number, for January 1966, of the bulletin, British Research and Development Reports, issued by the National Lending Library for Science and Technology, opens a series intended both to direct attention to the existence of such reports and to increase their flow. The reports are treated as part of the collection of the Library and will be available through its normal services. They include reports from defence or industrial organizations which have no security or commercial limitations on availability and reports from university laboratories containing so much numerical data that they are too large for normal publication. The subjects covered include science, technology (including agriculture and medicine) and the social sciences. The subject headings used are deliberately broad and in the first issue ontries are predominantly under engineering.

\section{The National Plan}

"The National Plan-Its Contribution to Growth" is the title of a broadsheet by Geoffrey Denton (Planning, 31, No. 493, 331. London: Political and Economic Planning, 1965. 6s.). Mr. Denton examines the nature of the Plan adopted by the past Government and tries to suggest how planning might be developed to the advan. tage of the British economy. Mr. Denton deals first with tho Plan as a forecast and then as a target and a feasibility study. He goes on to consider the Plan as a directive and deals finally with the value of such a plan and with the type of plan which is desirable. Mr. Denton thinks that the Plan cannot be regarded as an alternative to the major political changes which may be required, and he feels that the need to ensure appropriate democratic control over the planning process is a further argument for considering the implications of alternative rates of growth. The method by which an indicative target plan of this type can promote faster growth has not adequately been explained, and it may well be an uncertain basis for this operation. While showing awareness of the rolation between targets and the policy measures necessary to fulfil them, the Plan fails to indicate convineingly how the present balance of payment figuros ean be integrated with policy in a manner which can fill the gap between forecast and plan. National plans can nevertheless contribute much to the successful management of the economy. The broadsheet indicates one way in which the Plan could possibly be adapted to provide a faster rate of economic growth.

\section{University News:}

School of Pharmacy

THe Council of the School of Pharmacy, University of London, has conferred Honorary Fellowship of the School on Sir Harry Jepheott, in recognition of his great services to the School over many years. Sir Harry Jephcott has been chairman of the School Council since its formation in 1948 .

Dr. F. R. JEvons, at present lecturer in biological chemistry, has boen appointed to a newly established chair of liberal studies in scionce.

Strathclyde

D. S. Butlek, reader in numerical analysis in the Department of Mathematics at the University of Strathclyde, has been appointed professor of numerical analysis as from April 1.

\section{Sussex}

Prof. G. A. Sim, at present professor of physical chemistry in the University of Illinois, has been appointed professor of chemistry.

\section{Appointments}

DR. J. L. Goddard is to be commissioner of the Food and Drug Administration of the U.S. Department of Health, Education and Welfare. He was previously chief of the Communicable Disease Center, Public Health Service.

G. R. W. De Silva has been appointed director of the Division of Conference and General Services of the International Atomic Energy Agency in succession to D. G. Sullivan.

H. E. RILEY, formerly chief statistician at the International Labour Office, has been appointed head of the Office of Economic and Manpower Studies of the U.S. National Science Foundation.

\section{Announcements}

THE spring meeting of the British Biophysical Society, on "Excitable Tissues", will be held in the University of Oxford during April 14-15. Further information can be obtained from Dr. A. R. Peacocke, St. Peter's College, Oxford.

A symposium on "Aspects of Surface and Colloid Chemistry" will be held at the John Dalton College of Technology on April 15. Further information can be obtained from Dr. A. Powell, Department of Chemistry, John Dalton College of Technology, Chester Street, Manchester 1.

A MEETING of the 'Thermal Analysis Group of the Society for Analytical Chemistry will be held at the Royal College of Advanced Technology, Salford, during April 21-22. Further information can be obtained from the Society for Analytical Chemistry, 14 Belgrave Square, London, S.W.1.

A CONFERENCE on "Phonons", arranged by the Institute of Physics and the Physical Society, will be held in the University of Edinburgh during April 6-7. Further information can be obtained from tho Meetings Officer, the Institute of Physics and the Physical Society, 47 Belgrave Square, London, S.W.1. 